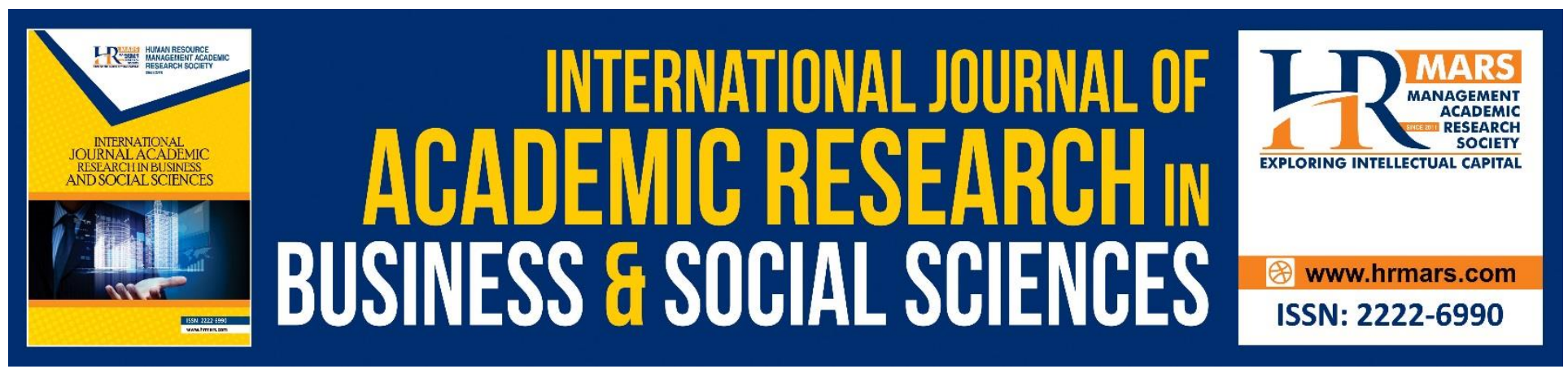

\title{
Market Capitalization and Financial Variables: Evidence from Italian Listed Companies
}

\section{Pietro Pavone}

To Link this Article: http://dx.doi.org/10.6007/IJARBSS/v9-i3/5802

DOI: $10.6007 /$ IJARBSS/v9-i3/5802

Received: 07 Feb 2019, Revised: 20 Feb 2019, Accepted: 1 March 2019

Published Online: 21 March 2019

In-Text Citation: (Pavone, 2019)

To Cite this Article: Pavone, P. (2019). Market Capitalization and Financial Variables: Evidence from Italian Listed Companies. International Journal of Academic Research Business and Social Sciences, 9(3), 1356-1371.

Copyright: (C) 2019 The Author(s)

Published by Human Resource Management Academic Research Society (www.hrmars.com)

This article is published under the Creative Commons Attribution (CC BY 4.0) license. Anyone may reproduce, distribute, translate and create derivative works of this article (for both commercial and non-commercial purposes), subject to full attribution to the original publication and authors. The full terms of this license may be seen

at: http://creativecommons.org/licences/by/4.0/legalcode

\section{Vol. 9, No. 3, 2019, Pg. 1356 - 1371}

Full Terms \& Conditions of access and use can be found at http://hrmars.com/index.php/pages/detail/publication-ethics 


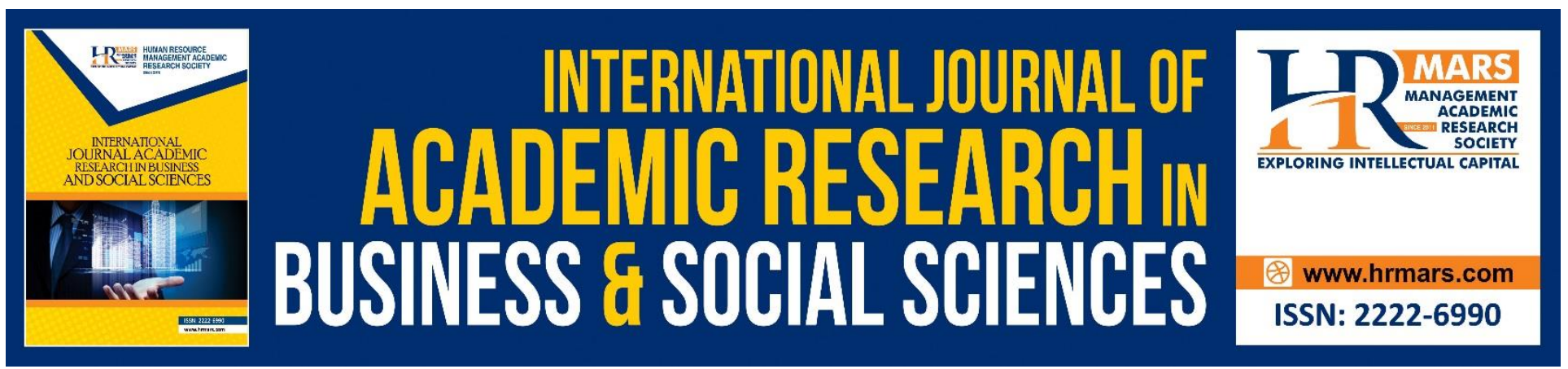

\title{
Market Capitalization and Financial Variables: Evidence from Italian Listed Companies
}

\author{
Pietro Pavone \\ Law, Economics, Management and Quantitative Methods Department, University of Sannio \\ Email: pietro.pavone@unisannio.it
}

\begin{abstract}
In the company-financial markets relationship, a crucial role is played by economic-financial information, because the financial variables deriving from the balance sheet analysis reduce the information asymmetries between management and potential investors and improve market efficiency. The present study is conducted to examine the effect of some financial variables on market capitalization. The market capitalization is considered as a dependent variable, while six are the independent variables: Return on Equity, Return on Assets, Price/Earnings Ratio, Operating Income/Turnover per share, Earnings Yield and Working Capital per Share. 307 Italian listed companies are considered. The study period is 10 years: from 2008 to 2017.

This research, while noting that the variables considered are not decisive drivers of the market capitalization, outlines some important relationships: positive relationship between market capitalization and Price/Earnings Ratio, Operating income/Turnover per share and Working Capital per Share and negative relationship between market capitalization and ROE, ROA and Earnings Yield. Keywords: Market Capitalization, Profitability Ratios, Market Value Ratios, Financial Variables, Italian Listed Companies.
\end{abstract}

\section{Introduction}

Market capitalization has a significant influence on the growth and development of the economy (Odogunde et al., 2006) and the role of this influence is growing.

In fact, the capital market has had a remarkable development over the last few decades and more and more companies are turning to it to obtain new risk capital and to diversify the overall risk. The process is also facilitated by the internationalization of capital procurement markets and by numerous innovations in negotiation techniques, as well as by the growing disintermediation of the banking system. 
The capitalization of a company is the product of the price of a share for the number of shares issued and listed. The sum of the capitalizations of companies listed on a market is equal to the value of the total capitalization of that financial market.

Market capitalization is an important market indicator of the value of shares and the value of companies in general (Toramane et al., 2009; Dias 2013). Most studies suggest that the macroeconomic environment has an important effect on the stock market capitalization rate (Kurihara, 2006; Odogunde et al., 2006). Thus, the price of shares on the market reflects both endogenous factors (depending on the development of the single issuing company) and exogenous factors or "scenario factors" relating to the general performance of the economy. It is generally difficult to identify the factors that most affect the stock price index. In recent decades, especially the interaction of the stock market with macroeconomic variables has been the subject of interesting studies (Rad, 2011). Instead, this research focuses on microeconomic factors.

The trend of market capitalization of the companies included in the sample subject of this study returns an overall increasing trend (as evidenced by the dashed trend line in Figure 1), but with some peaks that are connected to international economic events.

Figure 1: market capitalization in Italy in the period 2008-17 (values in millions of euros)

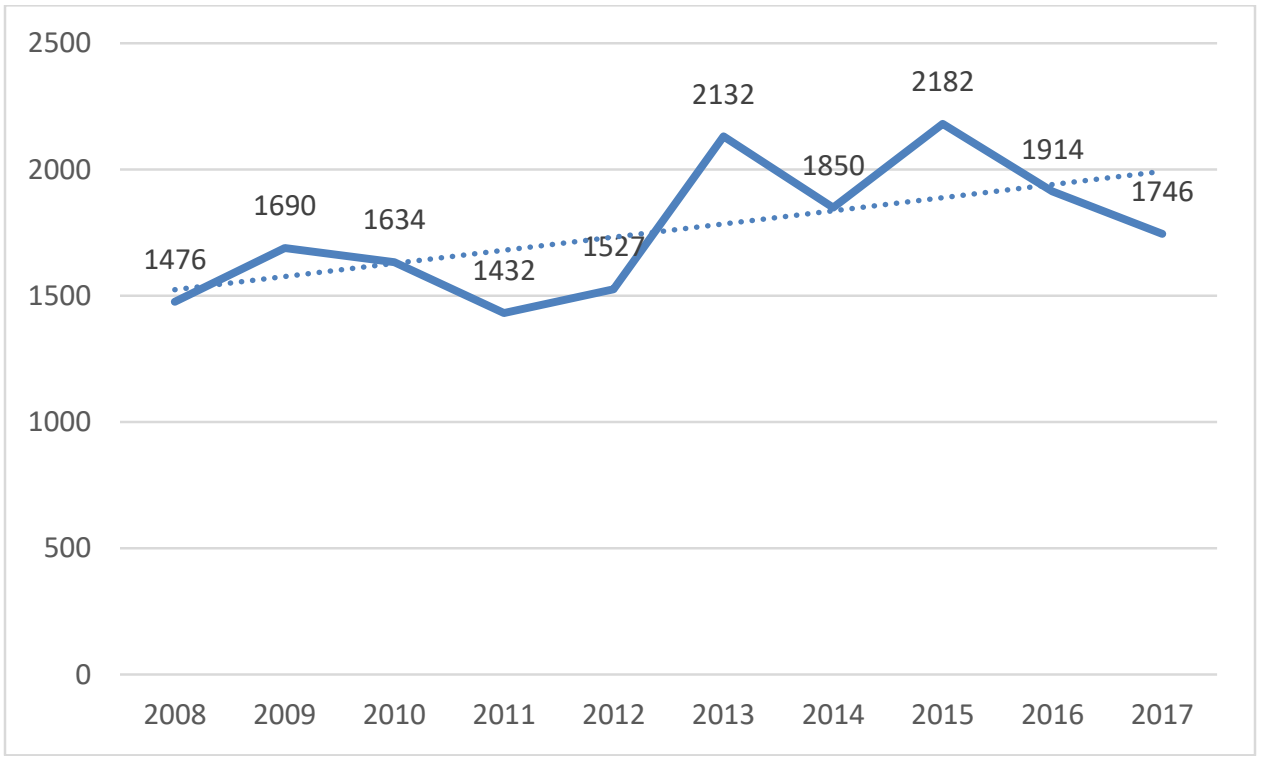

Source: author's elaboration

The lowest values of 2008 are because of the great economic crisis that originated in 2007 in the United States. The difficult and slow recovery immediately stopped between 2010 and 2011, also due to some speculative attacks against European Union countries registered in the financial markets in those years (initially Greece and later also Italy and the Spain). With the support of the ECB, since 2012, albeit in a fluctuating way, the capitalization values have increased: from an average value of 1500 in the first 2008-2012 period, the average value is almost 2000 if we consider the years from 2013 to 2017. 
Thus, the use of the stock market has increased especially in more recent years, both in terms of companies (with a growing diversification of sectors and average sizes, calculated on the basis of revenues, always greater) and in terms of the value of the shares, as highlighted from the sample data.

As it is known, there is a relationship between the trend of the stock and the performance of the company to which the stock refers. In this relationship that links the company to the financial market, economic-financial information plays a central role. This paper analyzes the theme of the relationship between balance sheet data and share price, therefore between balance sheet values and/or values derived from the balance sheet and stock market value. A practical contribution of the study is in the identification of a possible set of financial indicators that are more useful for the analyzes conducted on the financial markets, highlighting the most important management profiles of a company. This is valuable information for investors, and it is therefore important for companies to be able to communicate the most useful performance indicators to investors in their market reports. In this way the information asymmetry typical of financial markets would be reduced, facilitating the allocation of capital and the development of the positions of each actor involved in the

process. At the theoretical level, the research, contributing to the debate on the usefulness of internal indicators to explain external variables (the listing of shares) is part of the research sector of "value relevance studies".

\section{Theoretical Basis}

Financial statement information can indicate the value of a company based on a variety of information taken from the balance sheet and income statement. In fact, both the final figures and the hypotheses related to the planning of future management merge into the balance sheets. Therefore, the careful reading of the items and amounts shown in the balance sheets allows a first immediate judgment on the company's economic and equity structure. However, this judgment can be strengthened and better articulated if the financial statements are subjected to a series of reworkings, known as balance sheets analysis.

The business economics literature, in an initial phase, examined the reporting and predictive value of the various financial statement indices (Ferrero and Dezzani, 1979; Onida, 1985; Tieghi and Gigli, 2009), then investigating, at a later time and with very mixed results, how these indices could be useful in explaining other quantities (Narayan, et al., 2011; Burge, 2014; Graham and King, 2013; Diéguez, et al., 2014). This study is part of this second research perspective, proposing to understand if and to what extent some selected financial indices can help explain the market capitalization of companies. According to Sultan (2014), one of the main objectives of financial analysis is precisely to identify a relationship between changes in the financial trend and the company's performance. However, the relationship between a company's profits and the price of its shares can be difficult; high profits do not necessarily mean a high share price, just as large losses do not always lead to a low share price. Undoubtedly earnings are needed otherwise the company does not survive over time, but the price of the shares would be explained not only by the current profits but also by the promise of future earnings. The ratios certainly give evidence of the past management but also 
provide important indications on the perspective evolution. Therefore, they are often taken into consideration by investors.

Part of the studies (Peles and Schneller, 1982; Abdolmohammadi, 2005) indicated the significant role of profitability indicators in explaining market variables. For example, the study by Qurashi and Zahoor (2016) on market capitalization of Middle Eastern banks finds a positive relationship with ROI but no relationship with ROA and ROE.

A study of a sample of companies listed in Romania (Pantea, et al., 2014) indicates a positive and statistically significant relationship between some microeconomic factors and economic-financial performance.

The study by Jaya and Sunder (2012) focuses instead on the relationship between market capitalization and macroeconomic factors, highlighting that $91 \%$ of the change in market capitalization for the study period (2003-2011) is explained by the Equity and Liquidity variables.

Research conducted in China (Tan and Floros, 2001) indicates that there is a positive relationship between bank profitability, cost efficiency, banking sector development, stock market development and inflation.

Shobhana and Karpagavalli (2011), find a positive, and in some cases significant, relationship between dividend yeld and share price.

Instead, the study by Al Mubarak and Hamdan (2016) confirms the positive impact of good corporate governance on market capitalization of companies. Similar conclusions are also contained in another research, always on the relationship between good corporate governance and market capitalization (Hamdan et. al. 2013). The authors argue that corporate governance, by strengthening transparency and increasing investor confidence in financial statement disclosure, is implicitly reflected in the value of listed shares

The research of Prasetyantoko and Parmono (2008) focuses on the determinants of corporate performance of 238 companies listed in Indonesia. The main result is that the size was not related to market capitalization.

The study by Simpson and Evans (2003), relating to Australian banks in the period 1994-2002, finds no relationship between the stock market and selected macroeconomic variables.

Kuwornu and Victor (2011) test the relationship between macroeconomic variables and stock market returns using monthly data for the period 1992-008; the empirical results reveal that there is a significant negative relationship between stock market returns and exchange rate and treasury bill rate in Ghana.

\section{Objectives, Methodology and Structure of the Paper}

Several studies evaluate the relationship between market capitalization and macroeconomic variables. Taking a microeconomic perspective, this study focuses on the relationship between market capitalization and financial variables. Therefore, the main objective is to understand whether internal measures, derived from company balance sheets, are able to explain a variable, the market capitalization, with a strong external value. 
Thus, it is assumed that:

H1 the variables Return on Equity, Return on Assets, Price/Earnings Ratio, Operating Income/Turnover per Share, Earnings Yield and Working Capital per Share are positively associated with market capitalization.

$\mathrm{H} 2$ these relationships are statistically significant.

The research hypotheses are tested on a sample of 307 listed Italian companies, considered representative of the average stock market price of the population of Italian listed companies. Object of the research are some financial variables of this sample of Italian listed companies identified through the AIDA database of the Bureau van Dick company. At first, the sample consisted of 317 companies, but 10 were eliminated because there were no data available. The research considers the period 2008-2017. The time horizon is particularly significant because it allows us to also consider the effects of the financial crisis that began in 2007 in the United States and spread throughout the world from 2008 onwards.

The following profitability indexes are taken from the computerized database of the AIDA company:

1. Return on Equity;

2. Return on Assets;

3. Price/Earnings Ratio;

4. Operating Income/Turnover per Share

5. Earnings Yield (average high-low);

6. Working Capital per Share.

In addition to the first two classic profitability indicators, other financial indices are considered. The set of indicators constructed in this way is considered representative of both the economic and financial dimensions of the companies; moreover, it includes not only profitability ratios, but also market value ratios (such as the price/earnings ratio and earnings yield) which better represent the external dimension of investors besides the internal dimension of the company. The other variable needed to conduct the study is market capitalization, whose data is downloaded for the 2008-2017 period.

This research has a quantitative nature. Some considerations of descriptive statistics offer a picture of the trend of the indices during the considered period. Subsequently, an empirical model is constructed in which the data are examined using regression analysis.

In the conclusions, the results of the research are summarized, outlining also the limits, the possible future developments and the different implications.

\section{Results and Discussion \\ Descriptive Statistics}

Return on Equity

ROE compares net profit to equity and measures the company's overall profitability. Table 1 elaborates some statistics related to constantly growing available data: from 221 values in 2008 (72\%) to almost $90 \%$ in the last years of the decade in question.

The distribution of data around the average is mostly symmetrical, as shown by the almost coinciding average and median values over the decade (with an average deviation of 0,5 ) and asymmetry values not far from 0 . This means a fairly regular distribution, with few peaks in the 
INTERNATIONAL JOURNAL OF ACADEMIC RESEARCH IN BUSINESS AND SOCIAL SCIENCES

Vol. 9, No. 3, March, 2019, E-ISSN: 222 2-6990 @ 2019 HRMARS

values assumed by the ROE, however always positive even in the years immediately following the 2007-08 economic crisis.

\begin{tabular}{|l|c|c|c|c|c|c|c|c|c|c|}
\hline \multicolumn{10}{|c|}{ Table 1. Statistical data relating to ROE } \\
\hline \multicolumn{1}{|c|}{ Year } & $\mathbf{2 0 0 8}$ & $\mathbf{2 0 0 9}$ & $\mathbf{2 0 1 0}$ & $\mathbf{2 0 1 1}$ & $\mathbf{2 0 1 2}$ & $\mathbf{2 0 1 3}$ & $\mathbf{2 0 1 4}$ & $\mathbf{2 0 1 5}$ & $\mathbf{2 0 1 6}$ & $\mathbf{2 0 1 7}$ \\
\hline Tot. data & 221 & 225 & 228 & 229 & 231 & 260 & 274 & 277 & 276 & 274 \\
\hline $\begin{array}{l}\text { Values on 307 } \\
(\%)\end{array}$ & $\begin{array}{c}71,9 \\
\%\end{array}$ & $\begin{array}{c}73,2 \\
\%\end{array}$ & $\begin{array}{c}74,2 \\
\%\end{array}$ & $\begin{array}{c}74,5 \\
\%\end{array}$ & $\begin{array}{c}75,2 \\
\%\end{array}$ & $\begin{array}{c}84,6 \\
\%\end{array}$ & $\begin{array}{c}89,2 \\
\%\end{array}$ & $\begin{array}{c}90,2 \\
\%\end{array}$ & $\begin{array}{c}89,9 \\
\%\end{array}$ & $\begin{array}{c}89,2 \\
\%\end{array}$ \\
\hline & - & - & - & - & - & - & - & - & - & - \\
Min. & 116,6 & 143,1 & 118,5 & 140,8 & 119,8 & 142,6 & 141,1 & 128,4 & 137,3 & 123,9 \\
\hline Max. & 94,0 & 83,5 & 96,3 & 99,6 & 83,9 & 89,7 & 66,5 & 92,7 & 99,0 & 98,9 \\
\hline Range & 210,7 & 226,6 & 214,8 & 240,4 & 203,7 & 232,3 & 207,6 & 221,1 & 236,4 & 222,8 \\
\hline Mean & $\mathbf{5 , 9}$ & $\mathbf{3 , 1}$ & $\mathbf{7 , 2}$ & $\mathbf{5 , 8}$ & $\mathbf{4 , 4}$ & $\mathbf{2 , 2}$ & $\mathbf{0 , 1}$ & $\mathbf{3 , 1}$ & $\mathbf{4 , 4}$ & $\mathbf{4 , 7}$ \\
\hline Median & $\mathbf{5 , 7}$ & $\mathbf{4 , 1}$ & $\mathbf{5 , 8}$ & $\mathbf{5 , 1}$ & $\mathbf{4 , 3}$ & $\mathbf{3 , 9}$ & $\mathbf{3 , 0}$ & $\mathbf{4 , 4}$ & $\mathbf{5 , 0}$ & $\mathbf{5 , 5}$ \\
\hline $\begin{array}{l}\text { Average } \\
\text { deviation }\end{array}$ & 15,2 & 16,8 & 13,5 & 16,0 & 14,5 & 15,3 & 14,7 & 15,0 & 13,9 & 14,7 \\
\hline & 629,1 & & & & & & & & & \\
Variance & 8 & 824,3 & 507,5 & 758,1 & 600,4 & 721,5 & 694,0 & 679,6 & 586,1 & 599,9 \\
\hline Std. deviation & 25,0 & 28,7 & 22,5 & 27,5 & 24,5 & 26,8 & 26,3 & 26,0 & 24,2 & 24,4 \\
\hline Asymmetry & $-0,8$ & $-1,4$ & $-0,4$ & $-1,2$ & $-0,9$ & $-1,7$ & $-2,6$ & $-1,4$ & $-1,0$ & $-1,1$ \\
\hline
\end{tabular}

\section{Return on Assets}

ROA is given by the percentage ratio between operating result and total assets. It is often used because it can be easily calculated, considering that the values necessary for the calculation are immediately available. It has the same reporting power as ROI: this last index, however, requires the identification of the capital invested in operational management alone, which is not always easily obtainable.

Aida database makes available (table 2 ) from $74 \%$ to $97 \%$ of the ROA values of the companies in the sample. The range of variation is not very high, the median is very similar to the mean and the standard deviation values are very low: therefore, the variability intervals are marginal: 3,10 is the average value recorded at the beginning and end of the decade. 
INTERNATIONAL JOURNAL OF ACADEMIC RESEARCH IN BUSINESS AND SOCIAL SCIENCES Vol. 9, No. 3, March, 2019, E-ISSN: 222 2-6990 @ 2019 HRMARS

\begin{tabular}{|c|c|c|c|c|c|c|c|c|c|c|}
\hline & & & & & & & & & & \\
\hline Tot. & 8 & 1 & 6 & 247 & 51 & 280 & ח & 98 & 96 & 288 \\
\hline $\begin{array}{l}\text { Values on } 307 \\
(\%)\end{array}$ & $74,2 \%$ & $76,2 \%$ & $76,8 \%$ & $80,4 \%$ & $81,7 \%$ & $91,2 \%$ & $94,4 \%$ & $97 \%$ & $96,4 \%$ & $93,8 \%$ \\
\hline Min. & $-36,9$ & $-50,8$ & $\begin{array}{c}- \\
120,2\end{array}$ & $-60,4$ & $-62,7$ & $-70,2$ & $\begin{array}{c}- \\
102,4\end{array}$ & $\begin{array}{c}- \\
114,1\end{array}$ & $-53,4$ & $-64,1$ \\
\hline Max. & 46,4 & 38,7 & 81,4 & 67,1 & 297,5 & 119,6 & 151,6 & 180,2 & 127,8 & 150,5 \\
\hline Range & 83,4 & 89,5 & 201,7 & 127,6 & 360,3 & 189,8 & 254,1 & 294,3 & 181,2 & 214,7 \\
\hline Mean & 3,1 & 1,5 & 2,2 & 2,4 & 3,0 & 2,3 & 1,8 & 2,1 & 2,1 & 3,1 \\
\hline Median & 2,6 & 1,5 & 1,9 & 1,2 & 0,7 & 1,4 & 1,3 & 1,8 & 1,3 & 1,6 \\
\hline $\begin{array}{l}\text { Average } \\
\text { deviation }\end{array}$ & 6,6 & 6,6 & 6,9 & 6,9 & 8,2 & 6,1 & 6,5 & 7,1 & 6,4 & 6,6 \\
\hline Variance & 98,3 & 115,0 & 214,3 & 136,4 & 553,9 & 136,9 & 218,0 & 246,4 & 159,5 & 187,6 \\
\hline Std. deviation & 9,9 & 10,7 & 14,6 & 11,6 & 23,5 & 11,7 & 14,7 & 15,6 & 12,6 & 13,6 \\
\hline Asymmetry & $-0,0$ & $-0,7$ & $-3,1$ & $-0,0$ & 8,7 & 2,8 & 1,4 & 3,4 & 2,7 & 4,5 \\
\hline
\end{tabular}

\section{Price/Earnings Ratio}

This indicator is calculated as the ratio between the current market price of a share and the earnings per share, which in turn is equal to the ratio between total profits and the number of shares in circulation. It is often used to identify possible under-or over-valuations of listed companies with respect to their theoretical book values.

Aida database makes available (table 3) from $30 \%$ in 2008 to $57 \%$ in 2017 of the values of this index. The range of variation is very high: therefore, it is appropriate to combine the analysis of the arithmetic mean with the analysis of the median; amedian very far from the average means a considerable number of companies with a price/earnings ratio lower than the average of the sample.

The distribution is highly volatile, for reasons that may not be exclusively linked to the internal efficiency conditions of the examined companies; high values of this indicator may be due to the fact that the market evaluates in advance expectations of future profits of companies; likewise, sometimes the value is low because the market expects falling profits in the near future. In detail, 2017 shows values that are far higher than those of previous years. 
INTERNATIONAL JOURNAL OF ACADEMIC RESEARCH IN BUSINESS AND SOCIAL SCIENCES Vol. 9, No. 3, March, 2019, E-ISSN: 222 2-6990 @ 2019 HRMARS

\begin{tabular}{|c|c|c|c|c|c|c|c|c|c|c|}
\hline Year & 2008 & 2009 & 2010 & 2011 & \begin{tabular}{|c|}
201 \\
2 \\
\end{tabular} & 2013 & 2014 & 2015 & 2016 & 2017 \\
\hline Tot. data & 93 & 82 & 872 & 88 & 84 & 87 & 119 & 137 & 143 & 176 \\
\hline $\begin{array}{l}\text { Values } \\
\text { on } 307 \\
(\%)\end{array}$ & $30,2 \%$ & 26,7 & 28,3 & 28,6 & 27,3 & 28,3 & 38,7 & 44,6 & 46,5 & 57,3 \\
\hline Min. & 0 & 0 & 0 & 0 , & 0 & 0,01 & 0,01 & 0,01 & 0,02 & 1,3 \\
\hline Max. & 50460,3 & $\begin{array}{c}26309 \\
3 \\
\end{array}$ & 368309,1 & $\begin{array}{c}2089 \\
, 2 \\
\end{array}$ & \begin{tabular}{|c}
564 \\
2 \\
\end{tabular} & $\begin{array}{c}110281 \\
7\end{array}$ & $\begin{array}{c}118020 \\
7\end{array}$ & $\begin{array}{c}10037 \\
, 1\end{array}$ & $\begin{array}{c}118555 \\
1\end{array}$ & $\begin{array}{c}9067 \\
, 7 \\
\end{array}$ \\
\hline Range & 50460,3 & $\begin{array}{c}26309 \\
3 \\
\end{array}$ & 368309,1 & $\begin{array}{c}2089 \\
, 2 \\
\end{array}$ & $\begin{array}{c}564, \\
2 \\
\end{array}$ & $\begin{array}{c}110281 \\
7\end{array}$ & $\begin{array}{c}118020 \\
6\end{array}$ & $\begin{array}{c}10037 \\
, 1\end{array}$ & $\begin{array}{c}118555 \\
1\end{array}$ & $\begin{array}{c}9066 \\
, 3 \\
\end{array}$ \\
\hline Mean & 864,8 & 370,3 & 4518,3 & 41,7 & 27,9 & 2819,6 & 1673,3 & 118 & 2045,5 & 996 \\
\hline Median & 16,6 & 10,9 & 12,8 & 15,2 & 11,6 & 14,3 & 18,0 & 16,46 & 17, & 13,9 \\
\hline $\begin{array}{l}\text { Average } \\
\text { deviatio } \\
n\end{array}$ & 1613,7 & 677,67 & 8693,8 & 49,5 & 29,0 & 5263,8 & 3185,6 & 180,9 & 3843,1 & $\begin{array}{c}153 \\
1 \\
\end{array}$ \\
\hline Variance & $\begin{array}{c}309686 \\
92\end{array}$ & $\begin{array}{c}84696 \\
61\end{array}$ & $\begin{array}{c}15610121 \\
41\end{array}$ & $\begin{array}{c}4903 \\
5 \\
\end{array}$ & $\begin{array}{c}503 \\
6\end{array}$ & $\begin{array}{c}2236095 \\
45\end{array}$ & $\begin{array}{c}1560310 \\
84\end{array}$ & $\begin{array}{c}74234 \\
1\end{array}$ & $\begin{array}{c}1846161 \\
14\end{array}$ & $\begin{array}{c}4923 \\
6 \\
\end{array}$ \\
\hline $\begin{array}{l}\text { Srd. } \\
\text { deviatio } \\
n\end{array}$ & 5564,9 & 2910,2 & 39509,6 & $\begin{array}{c}221 \\
4\end{array}$ & 70,9 & 14953,5 & 12491,2 & 861,5 & 13587,3 & $\begin{array}{c}701 \\
6\end{array}$ \\
\hline $\begin{array}{l}\text { Asymme } \\
\text { try }\end{array}$ & 8,1 & 8,9 & 9,2 & 9,2 & 6,0 & 5,9 & 8,31 & 11,3 & 7,3 & 12,1 \\
\hline
\end{tabular}

\section{Operating Income/Turnover per Share}

It is the result of ordinary operations and is equal to the difference between the value of production obtained and the cost of production, regardless of financial charges; in other words, it is obtained by deducting depreciation and amortization from the gross operating margin. The operating income shows the income of the company before extraordinary and tax management, therefore it offers a value that does not include extraordinary events or fiscal interferences. When compared to turnover, it measures the profitability of turnover in terms of characteristic management. In practice, this relationship is very reliable, because no subjective assessments typical of budgetary policies are entered into the numerator and denominator.

The gap between media and median is very accentuated, as are the mean deviation and standard deviation values: the distribution is not homogeneous. Aida database makes available (table 4) an increasing percentage over the years of the parameter values: from 124 values in 2008 (40\%) to around $78 \%$ of the sample companies in the last years of the decade.

The trend is progressively decreasing, considering the median values, more reliable than the average ones. The maximum value occurs in $2008(6,89)$ and is about twice that recorded at the end of the decade $(3,44$ in 2017). The minimum value is in $2016(3,12)$. 
INTERNATIONAL JOURNAL OF ACADEMIC RESEARCH IN BUSINESS AND SOCIAL SCIENCES Vol. 9, No. 3, March, 2019, E-ISSN: 222 2-6990 @ 2019 HRMARS

\begin{tabular}{|c|c|c|c|c|c|c|c|c|c|c|}
\hline Yoar & 8 & & & & & & & & & \\
\hline tedata & 200 & 200 & 2 & 2 & 2012 & כוט & 20 & 20 & 2010 & \\
\hline did & & & & & & & & & & \\
\hline & $40,3 \%$ & $43,6 \%$ & $44,9 \%$ & $45,9 \%$ & $47,5 \%$ & $55,3 \%$ & $61,5 \%$ & $65,1 \%$ & $71,9 \%$ & $78,8 \%$ \\
\hline Min. & $-172,6$ & 0 & 0 & 0 & $-40,2$ & 0 & 0 & 0 & 0 & 0,00 \\
\hline Max. & $9.559,7$ & $\begin{array}{c}8.401 \\
4\end{array}$ & $\begin{array}{c}10.260 \\
2\end{array}$ & $9.115,5$ & $\begin{array}{c}36.865 \\
2\end{array}$ & $\begin{array}{c}10.315 \\
3\end{array}$ & $\begin{array}{c}10.913 \\
4\end{array}$ & $\begin{array}{c}11.808 \\
4\end{array}$ & $\begin{array}{c}11.413 \\
4\end{array}$ & 133,6 \\
\hline Range & $9.732,3$ & $\begin{array}{c}8.401 \\
4 \\
\end{array}$ & $\begin{array}{c}10.260 \\
2\end{array}$ & $9.115,5$ & $\begin{array}{c}36.905 \\
5\end{array}$ & $\begin{array}{c}10.315 \\
3\end{array}$ & $\begin{array}{c}10.913 \\
4\end{array}$ & $\begin{array}{c}11.808 \\
4\end{array}$ & $\begin{array}{c}11.413 \\
4\end{array}$ & 133,6 \\
\hline Mean & 237,3 & 186,7 & 204,7 & 173,5 & 456,6 & 240,2 & 161,7 & 124,5 & 84,9 & 9,3 \\
\hline Median & 68 & 5,4 & 5,1 & 5,0 & 4,1 & 4,0 & 3,6 & 3,3 & 3,1 & 3,4 \\
\hline $\begin{array}{l}\text { Average } \\
\text { deviation }\end{array}$ & 429,4 & 339,2 & 369,3 & 312,9 & 853,3 & 438,9 & 295,6 & 227,4 & 152,2 & 9,5 \\
\hline Variance & $\begin{array}{c}137102 \\
1\end{array}$ & $\begin{array}{c}96202 \\
0\end{array}$ & $\begin{array}{c}122137 \\
0\end{array}$ & $\begin{array}{c}101773 \\
7\end{array}$ & $\begin{array}{c}104209 \\
63\end{array}$ & $\begin{array}{c}140963 \\
5\end{array}$ & $\begin{array}{c}109341 \\
9\end{array}$ & $\begin{array}{c}100827 \\
5\end{array}$ & 723628 & 275 \\
\hline $\begin{array}{l}\text { Std. } \\
\text { deviation }\end{array}$ & 1170,9 & 980,8 & 1105,1 & 1008,8 & 3228,1 & 1187,2 & 1045,6 & 1004,1 & 850,6 & 16,5 \\
\hline $\begin{array}{l}\text { Asymmet } \\
\text { ry }\end{array}$ & 6,2 & ,3 & 6,9 & 7,0 & 10,2 & 5,8 & 7,9 & 9,7 & 12,0 & 4,0 \\
\hline
\end{tabular}

\section{Earnings Yield}

The return on profits refers to earnings per share for the last 12-month period compared to the current market price per share. Therefore, this index measures the speed with which a company's expected earnings will be capitalized in the next period.

Aida database shows (table 5) a not very high percentage of earnings / yield ratio: from 90 values in $2008(29 \%)$ to around $58 \%$ of the sample companies in the last years of the decade. 
INTERNATIONAL JOURNAL OF ACADEMIC RESEARCH IN BUSINESS AND SOCIAL SCIENCES Vol. 9, No. 3, March, 2019, E-ISSN: 222 2-6990 @ 2019 HRMARS

\begin{tabular}{|c|c|c|c|c|c|c|c|c|c|c|}
\hline Yoar & 2000 & 2000 & 2010 & 2011 & 20 & 2012 & 2 & & & ריו \\
\hline rear & 2000 & $\angle 00 Y$ & 2010 & 2011 & 2012 & 2013 & 2014 & & & 011 \\
\hline Tot. data & 90 & 80 & 882 & 89 & 88 & 94 & 123 & 142 & 157 & 178 \\
\hline $\begin{array}{l}\text { Values on } \\
307(\%)\end{array}$ & $29,31 \%$ & $26,0 \%$ & $28,6 \%$ & $28,9 \%$ & $28,6 \%$ & $30,6 \%$ & $40,0 \%$ & $46,2 \%$ & $51,1 \%$ & $\begin{array}{c}57,9 \\
\%\end{array}$ \\
\hline Min. & 0,1 & 0,3 & 0,1 & 0,6 & 0,1 & 0,2 & 0,1 & 0,1 & 0,1 & 0,1 \\
\hline Max. & \begin{tabular}{|c|}
10814 \\
4 \\
\end{tabular} & $\begin{array}{c}11273 \\
0 \\
\end{array}$ & \begin{tabular}{|c|}
10480 \\
1 \\
\end{tabular} & 8517,3 & \begin{tabular}{|c|}
14182 \\
2 \\
\end{tabular} & $\begin{array}{c}10227 \\
3 \\
\end{array}$ & 8579,7 & $\begin{array}{c}8001 \\
6 \\
\end{array}$ & 4651,1 & 82,7 \\
\hline Range & $\begin{array}{c}10814 \\
3 \\
\end{array}$ & $\begin{array}{c}11272 \\
7\end{array}$ & $\begin{array}{c}10480 \\
0 \\
\end{array}$ & 8516,7 & $\begin{array}{c}14182 \\
0\end{array}$ & $\begin{array}{c}10227 \\
1 \\
\end{array}$ & 8579,6 & $\begin{array}{c}8001 \\
4 \\
\end{array}$ & 4651,0 & 82,6 \\
\hline Mean & 607,0 & 473,7 & 436,9 & 315,9 & 695,0 & 382,1 & 244,8 & 128,9 & 67,8 & 7,6 \\
\hline Median & 7,8 & 8,4 & 7,8 & 7,4 & 8,1 & 6,4 & 5,1 & 5,4 & 6,5 & 6,1 \\
\hline $\begin{array}{l}\text { Average } \\
\text { deviation }\end{array}$ & 1117,7 & 870,9 & 808,2 & 586,5 & 1273,9 & 702,1 & 454,6 & 241,1 & 116,5 & 4,7 \\
\hline Variance & \begin{tabular}{|c|}
516368 \\
8 \\
\end{tabular} & $\begin{array}{c}375582 \\
5\end{array}$ & $\begin{array}{c}331491 \\
1\end{array}$ & $\begin{array}{c}221067 \\
6\end{array}$ & $\begin{array}{c}719864 \\
9\end{array}$ & $\begin{array}{c}282995 \\
3 \\
\end{array}$ & $\begin{array}{c}164543 \\
0\end{array}$ & $\begin{array}{c}75991 \\
9 \\
\end{array}$ & $\begin{array}{c}26793 \\
8 \\
\end{array}$ & 85,0 \\
\hline $\begin{array}{l}\text { Std. } \\
\text { deviation }\end{array}$ & 2272,3 & 1937,9 & 1820,6 & 1486,8 & 2683,0 & 1682,2 & 1282,7 & 871,7 & 517,6 & 9,2 \\
\hline $\begin{array}{l}\text { Asymmet } \\
\text { ry }\end{array}$ & 3,6 & 4,3 & 4,3 & 4,9 & 4,0 & 4,7 & 5,5 & 7,4 & 8,7 & 4,7 \\
\hline
\end{tabular}

The decreasing trend of the arithmetic mean shows a clear discontinuity in 2012: 695, while the previous value was 315 in 2011 and the next one was 382 in 2013. The distribution is highly discontinuous with high values of average and standard deviation: the average is therefore not very indicative. The lower values of the second period of the decade are considered more reliable, also because they relate to a greater number of available data.

Working capital per Share

Working capital is calculated as current assets minus current liabilities. It is a financial metric which represents operating liquidity available to a business. In this study the reference of the value is to the single action. This is a very important parameter because a company can be endowed with assets and profitability but may fall short of liquidity if its assets cannot be readily converted into cash. To consider this parameter means to consider inventories, accounts receivable and payable, and cash. If a company has substantial working capital, then it should have the potential to invest and grow. If a company's current assets do not exceed its current liabilities, then it may have trouble growing or paying back creditors, or even go bankrupt.

The trend is progressively decreasing, considering the median values, more reliable than the average ones. The maximum value is in $2008(1,17)$ and is approximately four times that recorded at the end of the decade $(0,27$ in 2017, which is also the minimum value). In addition to the divergence between mean and median values, even the high mean and standard deviation values suggest an asymmetric and heterogeneous data distribution. 
INTERNATIONAL JOURNAL OF ACADEMIC RESEARCH IN BUSINESS AND SOCIAL SCIENCES

Vol. 9, No. 3, March, 2019, E-ISSN: 222 2-6990 ¿ 2019 HRMARS

Table 6. Statistical data relating to WORKING CAPITAL PER SHARE

\begin{tabular}{|l|c|c|c|c|c|c|c|c|c|c|}
\hline \multicolumn{10}{|c|}{ Table 6. Statistical data relating to WORKING CAPITAL PER SHARE } \\
\hline \multicolumn{1}{|c|}{ Year } & $\mathbf{2 0 0 8}$ & $\mathbf{2 0 0 9}$ & $\mathbf{2 0 1 0}$ & $\mathbf{2 0 1 1}$ & $\mathbf{2 0 1 2}$ & $\mathbf{2 0 1 3}$ & $\mathbf{2 0 1 4}$ & $\mathbf{2 0 1 5}$ & $\mathbf{2 0 1 6}$ & $\mathbf{2 0 1 7}$ \\
\hline Tot. data & 124 & 134 & 138 & 141 & 146 & 170 & 189 & 200 & 221 & 242 \\
\hline $\begin{array}{l}\text { Values on 307 } \\
\text { (\%) }\end{array}$ & $40,3 \%$ & $43,6 \%$ & $44,9 \%$ & $45,9 \%$ & $47,5 \%$ & $55,3 \%$ & $61,5 \%$ & $65,1 \%$ & $71,9 \%$ & $78,8 \%$ \\
\hline Min. & $-6,12$ & $-6,08$ & $-16,80$ & $-41,44$ & $-4,67$ & $-8,34$ & $-9,68$ & $-6,48$ & $-2,63$ & $-3,21$ \\
\hline Max. & $2.509,15$ & $1.986,81$ & $1.966,96$ & $1.854,43$ & $2.610,26$ & $2.171,51$ & $1.891,33$ & $1.957,71$ & $2.058,64$ & 29,50 \\
\hline Range & $2.515,27$ & $1.992,89$ & $1.983,75$ & $1.895,86$ & $2.614,93$ & $2.179,85$ & $1.901,00$ & $1.964,19$ & $2.061,26$ & 32,71 \\
\hline Mean & 73,40 & 48,07 & 47,47 & 33,77 & 64,09 & 43,41 & 25,98 & 20,50 & 15,98 & 1,39 \\
\hline Median & 1,17 & 0,89 & 0,65 & 0,80 & 0,71 & 0,42 & 0,38 & 0,27 & 0,28 & 0,27 \\
\hline $\begin{array}{l}\text { Average } \\
\text { deviation }\end{array}$ & 133,22 & 86,91 & 86,48 & 61,71 & 117,61 & 79,82 & 47,42 & 37,67 & 29,10 & 1,80 \\
\hline Variance & 121002,75 & 62874,51 & 62849,75 & 37034,95 & 108096,25 & 57992,19 & 29970,61 & 27543,57 & 25018,72 & 10,71 \\
\hline Std. deviation & 347,85 & 250,74 & 250,69 & 192,44 & 328,77 & 240,81 & 173,12 & 165,96 & 158,17 & 3,27 \\
\hline Asymmetry & 6,00 & 6,47 & 6,59 & 7,41 & 6,06 & 6,90 & 8,50 & 9,76 & 11,56 & 4,68 \\
\hline
\end{tabular}

Research models and regression analysis

In order to answer the research questions, a probabilistic research model is created to explain a variable based on other variables; therefore, the dependent variable (market capitalization) is isolated from the independent variables (ROE, ROA, PER, OIT, EYA, WCS). Therefore, it is possible to explain market capitalization as a function of ratios:

$$
M C=c+\beta 1 R O E+\beta 2 R O A+\beta 3 P E R+\beta 4 O I T+\beta 5 E Y A+\beta 6 W C S+\varepsilon
$$

where:

MC means Market Capitalization;

ROE is Return on Equity;

ROA is Return on Assets;

PER indicate Price/Earnings Ratio;

OIT indicate Operating Income/Turnover per Share;

EYA represents Earnings Yield (Average);

WCS is Working Capital per Share;

$c$ is a mathematical constant;

from $\beta 1$ to $\beta 6$ are the regression coefficients;

$\varepsilon$ indicates the approximation error.

First, the linearity relations between the different variables are studied using the Pearson coefficient ( $\rho)$, a dimensionless index between -1 and 1 useful for studying the extension of a linear relationship between two or more data sets. 
INTERNATIONAL JOURNAL OF ACADEMIC RESEARCH IN BUSINESS AND SOCIAL SCIENCES Vol. 9, No. 3, March, 2019, E-ISSN: 222 2-6990 @ 2019 HRMARS

\begin{tabular}{|r|r|r|r|r|r|r|r|}
\hline \multicolumn{6}{|c|}{ Table 7. Correlation analysis between variables at 1\% and 5\% level of significance } \\
\hline MC & MC & \multicolumn{1}{c|}{ ROE } & ROA & PER & OIT & \multicolumn{1}{c|}{ EYA } & WCS \\
\hline ROE & 1 & $-0,5958$ & - & & - & - & - \\
\hline ROA & & 1 & 0,4918 & 0,1742 & 0,0543 & 0,2166 & 0,2613 \\
\hline PER & & & 1 & 0,3502 & 0,2425 & 0,2093 & 0,2090 \\
\hline OIT & & & 1 & - & - & - \\
\hline EYA & & & & & 0,5424 & 0,4952 & 0,5294 \\
\hline WCS & & & & & 1 & 0,8951 & 0,8262 \\
\hline
\end{tabular}

Source: author's elaboration

Table 7 shows mainly negative correlations: in detail, between ROE, ROA, OIT, EYA, WCS and the dependent variable $\mathrm{MC}$ there is a moderate negative correlation; instead, there is a very weak positive correlation between MC and PER $(0,0832)$; while all the other variables are negatively correlated with MC.

Then, all the variables are considered for the subsequent regression test, used to estimate the regression coefficients of the equation described above. The following table 8 shows the results of the regression test.

\begin{tabular}{|c|c|c|c|c|}
\hline \multicolumn{5}{|c|}{ Table 8. Regression test. Summary } \\
\hline Variables & c & $\beta$ & t-value & p-value \\
\hline & 2159 & & 7,8521 & 0,0043 \\
\hline ROE & & $-44,3645$ & $-1,2036$ & 0,3150 \\
\hline ROA & & $-264,4707$ & $-1,5337$ & 0,2226 \\
\hline PER & & 0,0005 & 1,5215 & 0,2254 \\
\hline OIT & & 3,6143 & 2,1087 & 0,1255 \\
\hline EYA & & $-5,2071$ & $-2,6348$ & 0,0780 \\
\hline WCS & & 36,5200 & 2,2421 & 0,1107 \\
\hline $\mathbf{R}$ & 0,9201 & & & \\
\hline R Square & 0,8466 & & & \\
\hline $\begin{array}{ll}\text { Adjusted } & \mathbf{R} \\
\text { Square } & \end{array}$ & 0,5398 & & & \\
\hline $\mathbf{F}$ & 2,7595 & & & \\
\hline $\begin{array}{c}\text { Sig.Prob } \\
\text { statistic) }\end{array}$ & 0,2171 & & & \\
\hline
\end{tabular}

Source: author's elaboration 
The value of $R$ Square is very high; however, since it is a multiple regression, the value of Adjusted $R$ Square $(0,5398)$ is considered. This value indicates that the model can explain the reports covered by this study for about $54 \%$ : this means that the variability of market capitalization is captured by this model for $54 \%$, while for the remaining $46 \%$ it is explained by other factors not included in the model.

Table 8 first shows three negative relationships: the first between $M C$ and ROE, the second between $M C$ and ROA and finally between MC and EYA, however in all three cases the $p$-value is higher than 0,05 , so the relationships are not statistically significant. Instead, $M C$ is positively linked $(\beta>0)$ to PER, OIT and WCS; but even these relationships cannot be considered statistically significant: $p$ value $(0,22,0,12$ and 0,11$)>0,05$.

\section{Conclusion}

This paper explains the importance of using profitability ratios and market value ratios as tools to understand market capitalization.

In fact, the study reveals some relationships between the quantities considered, but of different sign ( $\mathrm{H} 1$ is partially confirmed): there is a positive relationship between market capitalization and PER, OIT and WCS and a negative relationship between MC and ROE, ROA and EYA. From the regression analysis, the described relationships are not significant ( $\mathrm{H} 2$ is not confirmed). Although not statistically significant, they are still considered useful for the formulation of tendential judgments.

The main limitation of the research is constituted by the high sectorial differentiation of the companies in the sample and, therefore, by the substantial differences between the various economic cycles that are certainly reflected in the calculation of the indices. Therefore, further future studies can be conducted using a sectoral approach, which allows to strengthen the precision of estimation and to develop useful comparative intersectoral analyzes.

However, considering that the sample subject of this research consists only of listed companies, the most important in the Italian economy, the established relationships between variables can help to understand which indexes are more useful, both for decision-making purposes of operators and investors, and both for regulatory purposes, of the independent Authorities that regulate and control listed companies.

\section{Research Implications}

This study adds a real contribution to the understanding of the market capitalization-financial variables relationship, both at an academic and managerial level.

The increase in market capitalization values in Italy is due to the increase in the number of shares in circulation, but the main driver is the increase in share prices. The growth in the value of shares is explained by macroeconomic factors, but it is primarily due to endogenous factors. The originality of this study is represented precisely by having combined capitalization data with internal information of the company, assuming a microeconomic perspective, not deepened enough by the economic literature.

The research, therefore, empirically analyzes the determinants of market capitalization in Italy, endeavoring to relate internal variables (financial ratios) with an external quantity (MC), responding 
to the need to make the process of appreciation of expected benefits less discretionary from company activity. In fact, the concept of value creation, reflected in the price of the shares and the reason for the existence and development of the company, does not have a univocal definition, qualifying both on the basis of future expectations and on the basis of the subjective appreciation of these expected benefits by investors.

The financial community is strongly interested in measuring or predicting the evolutionary trends of this value, and the development of the company depends on its decisions; therefore there is a crucial role of the management that seeks not the maximization of a predetermined variable, but the optimization of a set of values compatible with the maximization of the capitalization value. Based on the indications of this study, managers and investors can make better decisions and better plan their business. Managers could consider PER, ROF and WCS as predictive indicators of capitalization trends. The correlation is not high but understanding the relationship could influence some fundamental decisions for the future of the company, such as the decision to carry out an IPO or postpone it to subsequent development phases.

\section{References}

Abdolmohammadi, M. J. (2005). Intellectual capital disclosure and market capitalization. Journal of Intellectual Capital, 6(3), 397-416.

Al Mubarak, M. M. S. and Hamdan, A. M. M. (2016). The impact of corporate governance on market capitalization: evidence from Bahrain bourse. Corporate Ownership \& Control, 13(3), 121130.

Burge, G. (2014). The capitalization effects of school, residential, and commercial impact fees on undeveloped land values. Regional Science and Urban Economics, 44, 1-13.

Dias, A. (2013). Market Capitalization and Value-at-Risk. Journal of Banking \& Finance, 37(12), 52485260.

Diéguez, A. I., González-Villegas, J.B. and Dolores Oliver-Alfonso, M. (2014). The Financial Performance of an Innovative Megaproject. Procedia. Social and Behavioral Sciences, 119, 417-426.

Ferrero, G. and Dezzani, F. (1979). Manuale delle analisi di bilancio. Indici e flussi. Milano, Giuffrè.

Graham, R. C. and King, R. D. (2013). Decision Usefulness of Whole-Asset Operating Lease Capitalizations. Advances in Accounting, 29(1), 60-73.

Hamdan, A., Al-Sartawi, A., and Jaber, R. (2013). The Effect of Corporate Governance on the Financial and Operational Performance and of Stock Performance in Kuwait Stock Exchange. Arab Journal of Administrative Sciences, 20(2), 255-302.

Jaya, M. and Sundar, K. (2012). A Study On The Relationship Of Market Capitalization And Macro Economic Factors (With Special Reference To Indian Information Technology Industry). Zenith International Journal Of Business Economics \& Management Research, 2(11).

Kurihara, Y. (2006). The Relationship between Exchange Rate and Stock Prices during the Quantitative Easing Policy in Japan. International Journal of Business, 11, 375-386.

Kuwornu, J. and Victor, O. N. (2011). Analyzing the Effect of Macroeconomic Variables on Stock Market Returns: Evidence from Ghana. Journal of Economics and International Finance, 3(11), 605-615. 
INTERNATIONAL JOURNAL OF ACADEMIC RESEARCH IN BUSINESS AND SOCIAL SCIENCES

Vol. 9, No. 3, March, 2019, E-ISSN: 222 2-6990 @ 2019 HRMARS

Mohammad, J. and Abdolmohammadi, M. (2005). Intellectual capital disclosure and market capitalization. Journal of Intellectual Capital, 6(3), 397-416.

Narayan, P. K., Mishra, S. and Narayan, S. (2011). Do market capitalization and stocks traded converge? New global evidence. Journal of Banking \& Finance, 35(10), 2771-278.

Odogunde, A. O., Elumilade, D. O. and Asaolu, T. O. (2006). Stock Market Capitalization and Interest Rate in Nigeria: A Time Series Analysis. International Research Journal of Finance and Economics, 4, 154-166.

Onida, P. (1985). Economia d'azienda. Torino, Utet.

Pantea, M., Gligor, D. and Anis C. (2014). Economic Determinants of Romanian Firms' Financial Performance. Procedia. Social and Behavioral Sciences, 124, 272-28.

Peles, Y. C. and Schneller M. I. (1982). Financial Ratios and The Analysis of Marketing Policy. European Journal of Marketing, 16(5), 12-21.

Prasetyantoko A. and Parmomo, R. (2008). Determinants of Corporate Performance Of Listed Companies In Indonesia. MPRA Paper.

Qurashi, M. and Zahoor, M. (2016). Impact of profitability, bank and macroeconomic factors on the market capitalization of the Middle Eastern banks. International Journal of Business and Management Invention, 5(11), 56-62.

Rad, A. A. (2011). Macroeconomic Variables and the Stock Market: Evidence from Iran. International Journal of Economic and Finance Studies, 3(1), 1-10.

Shobhana, V. K. and Karpagavalli, R. (2011). Determinants Of Market Price Of Shares Of The Select Banking Companies Listed On Bombay Stock Exchange. Academicia, 1(3), 8-25.

Simpson, J. L. and Evans, J. P. (2003). Banking Stock Returns and Their Relationship to Interest Rates and Exchange Rates: Australian Evidence. University of Wollongong, Dubai Working Paper,135.

Sultan, A. S. (2014). Financial Statements Analysis - Measurement of Performance and Profitability: Applied Study of Baghdad Soft-Drink Industry. Research Journal of Finance and Accounting, 5(4).

Tan, Y. and Floros, C. (2012). Bank profitability and inflation: the case of China. Journal of Economic Studies, 39(6), 675- 696.

Tieghi. M. and Gigli. S. (2009). Gli strumenti per e analisi di bilancio, Bologna, II Mulino.

Toraman, C., Aydemir O. and Demirhan, E., (2009). The Long Run Relationship Between Stock Market Capitalization Rate and Interest Rate: Co-integration Approach, International Research Journal of Finance and Economics, 23, 208-215. 